\title{
THE CAMPAIGN
}

\section{2 \\ Chance hai: from the campaign trail

\author{
Brij V. Lal
}

Balata, Dabota, Tagi Tagi, Garampani: these are distant, even vaguely exotic, names to this Labasa-born lad. They are, in fact, names of hauntingly beautiful places, evoking the sight, sound and smell of growing up in a rural settlement more than half a century ago. The same sprawling, rippling sea of cane fields, people going about their business on horseback or bicycle, weather-beaten faces of sons of the soil, their leathery skin cracked by excessive kava drinking. People show the hospitality and humanity that rural folk everywhere will recognize instantly. A hot cup of tea materializes quickly even in the poorest of homes, along with the invitation to stay over for a meal. These touching gestures remain with you long after you are gone.

I am travelling through western Viti Levu, trying to get some sense of what rural folk think about the election, the stories they might have to tell of what they have seen or heard. Everywhere, I am greeted with respect and affection, even, or especially, by those who think I am with the enemy, meaning the National Federation Party (NFP). At least you haven't become independent, one man says with a chuckle, a not too subtle reference to those who, unable to secure a party ticket and for one excuse or another, are standing as independents. Astoundingly, in this election there are more than 60 independents. What impact they will have on the final outcome is causing concern to party strategists. (None, as it turned out in the end). 
In rural areas, the normal rhythm of life continues largely undisturbed by what is happening in the country at large. A few pocket meetings ${ }^{1}$ here and there, the occasional talk by a visiting politician or the local candidate, but little more than that. In urban areas, it is a different story. There, the campaign in its early stages is full of talk of betrayal and treacherous preferencing, about intimidation and fear and vote-rigging. Both the SDL (Soqosoqo Duavata ni Lewenivanua) and Labour (the Fiji Labour Party or FLP) accuse NFP of reneging on preference deals, which the NFP vehemently denies - but not to any great effect. The party recognizes its minority status, a far cry from its glory days when it was the major party of the Indo-Fijian community. It gives its first preferences to Labour in predominantly Indo-Fijian areas and to the SDL in several winnable open seats in southeastern Viti Levu. Labour accuses NFP sarcastically of not knowing whether it is 'Arthur or Martha', that is, whether it is a party of and for the Indo-Fijians first and foremost or whether it has multi-ethnic identity and aspirations, while the SDL uses NFP's preference distribution to rally the Fijians behind it, telling them that both NFP and FLP are secretly consolidating Indo-Fijian support between them and that Fijians should do the same under the SDL's broad umbrella. Divide and rule is the name of the game, and all the parties know it: unite your own ethnic constituency and divide enough of your opponents to win. I find the charge of betrayal hollow.

I listen to the radio, religiously watch the evening news on television, buy and read all the newspapers. There are so many issues lurking in the background that desperately need to be discussed, but they aren't. It's as if everyone is avoiding hard, controversial topics in the campaign. The Promotion of Reconciliation, Tolerance and Unity Bill (RTU Bill) is one of them. The government says it wants to use the RTU Bill to bring closure to the painful events of 2000, but its opponents see it as a barely veiled attempt to grant amnesty to the coup-plotters whose support the SDL needs, especially among the nationalist sections of the Fijian community. The fact that some (notably former vice president Ratu Jope Seniloli) have been released from prison on compulsory supervision orders raises doubts and nurtures suspicion about the government's true motives. There is massive objection to the Bill from community and non-government organizations. Petitions are sent in the 
hundreds and protest marches are organized, reminding me of the 'Back to May' movement against the May coup in 1987. The Fiji military forces commander, Frank Bainimarama, thunders ominously that the RTU Bill will simply 'not happen'. To emphasize his point and to remind the country of his authority, he joins 500 of his fully armed men on a march through Suva the day parliament is dissolved. Bainimarama is angry, he says privately, because the government is not really in charge and the country is being run by two unelected men: Jioji Kotabalavu, the chief executive officer of the prime minister's office, and Senator Qoriniasi Bale, the Attorney General.

The country is deeply divided over the rift between the military and the government. There are some who applaud Bainimarama's tough, no-nonsense approach. FLP president Jokapeci Koroi, asked on television about her views on the army's confrontational attitude to the government, says that she would have no qualms about the army overthrowing the Qarase government and putting Labour back in power to continue its 'unfinished business'. I am astounded by the utter brazenness of the statement from the head of a party which itself had been a victim of the army's intervention in 1987. Later, seeking to deflect the issue, she says she was quoted out of context, but I have seen the interview with my own eyes, and she was not misquoted. The government calls for her resignation, but the matter is not followed through. As the campaign progresses, the issue quietly slips away. In many places, I hear Indo-Fijians actually supporting the army's stance. As one person tells me, in Hindi, 'We will take aim at them [meaning the SDL] by placing the gun on the shoulders of the soldiers'. 'You need steel to cut steel', another says to me in a tone that I find somewhat disturbing. 'The army is with us', Labour tells the electorate. 'There will be no coup. Don't be afraid. Vote for us without fear.' The message is repeated in pocket meeting after pocket meeting. It is effective in rallying wavering supporters to the party in the dying days of the campaign.

On the Fijian side, there is genuine discomfort about the army's increasingly confrontational statements. Many feel the army is overstepping its constitutionally defined role. In newspaper advertisements and on radio and television, Laisenia Qarase makes this point repeatedly. He wants the Supreme Court to rule on the proper constitutional position of the army in a Westminster-type democracy. There are some who are calling for the 
government to discipline the commander and cannot fathom the government's reluctance to move. But there is confusion about the proper procedure to use for this. On the eve of the elections, the widely admired Vice President Ratu Joni Madraiwiwi, a high chief in his own right, convenes a meeting between Qarase and Bainimarama to cool the temperature of the public spat between them. A vaguely worded accord is negotiated, and there is a palpable sigh of relief in the country, accompanied by a foreboding sense that things could go wrong at any time. As the campaign concludes, the army's strident intervention in the public arena has pushed many Fijians to the SDL side. Ironically, the army has achieved a result it wanted to prevent in the first place: SDL's increased popularity among Fijians.

In a radio interview, I am asked about the army's antics. My view is clear, and directly opposite to the military's, which sees an increased role for itself in the public life of Fiji. 'It is better to prevent the mess at the outset' one officer tells me, 'than to be called in to clean it up after the event.' Pakistan is cited as a model. I don't think it is the army's role to interpret the public's will, I say. Its role should be to enforce the public will, not to interpret or pre-empt it. My words are published in the papers and, for a brief moment, I wonder whether I should be so incautious in my public statements. 'Watch out, Doc', a Fijian nationalist candidate says to me at the Dolphins Foodcourt in Suva, slapping me playfully on the shoulder. He was the same person who had staged a public confrontation with me at a Reeves Commission hearing in Suva and had called on television for my resignation. He made the headlines. But when I met him in Korovou a few weeks later, he said politely that he hoped I did not mind what he had said about me. He was standing for a by-election, and wanted some free media attention, which the episode had given him. But I am troubled for a brief moment only: I have to be true to my convictions.

Another issue burning in the background is the expiry of agricultural leases under the Agricultural Landlord and Tenant Act (ALTA). The leases began expiring in the late 1990s. Now, there are thousands of farmers whose leases have not been renewed, who are uprooted and beginning new careers as casual labourers, small vegetable growers and domestic hands, crowding the already clotted Suva-Nausori corridor. I am told that in the Nasinu constituency contested by Labour's Labasa-born Krishna Datt, fully 40 per cent of the voters 
are displaced Labasans. There is quiet resentment against them - resentment about their industry and enterprising spirit, their preparedness to work for any wage. 'This place stinks of Labasa'; 'Labasa, Labasa gandhaye', a taxi driver tells me as we drive from Kinoya to Tacirua via the Khalsa road, not knowing that I too am from the 'friendly north'. There is intense competition for the squatter vote. But about a major cause of that problem, the expiry of leases, nothing much is said. SDL wants to renew the leases under the Native Land Trust Act (NLTA), which gives the landowner more say and greater flexibility on the renewal of leases, while Labour prefers the ALTA, whose tenant-favouring 'hardship clause' places greater onus on the landowner to prove that his need to reoccupy his land is greater than the tenant's.

The NFP proposes the concept of a 'Master Lease' under which the government would lease land from the landlords under the provisions of the NLTA and then lease it to the tenants under the terms of the ALTA. The idea was first proposed by Jai Ram Reddy and Wadan Narsey in the late 1990s, but it goes nowhere in this campaign. People are reluctant to engage seriously with ideas and alternatives, I begin to realize, preferring instead the comfort of the simple slogans. As I travel through the countryside, I see displaced tenants by the roadside selling root crops, vegetables and fish. The look on their sun-bathed, anguished, furrowed faces touches the heart. Through no fault of their own, they have become refugees in their own homeland. I see formerly productive cane fields slowly reverting to bush. A Fijian farmer, deep in the heartland of Viti Levu, tells me about the situation in his area. Many leases were not renewed and tenants had to move to the town. 'NLTA or Calcutta', some village wit had remarked. But after a few years, the landowners realized their error in the absence of the income that the lease rents brought, and pleaded with the former tenants to return. Most refused.

The land issue is closely tied to the uncertain fortunes of the country's ailing sugar industry. The preferential access to the European Union markets will soon expire, forcing Fiji to sell sugar on an internationally competitive market. The sugar mills function on ancient machines habitually prone to repeated breakdowns. The increasing cost of transporting cane to the mills and of hiring labourers is being felt by the growers. The uncertainty of renewal of leases creates its own problems. The government has talked about re-structuring the sugar 
industry, following the advice of an Indian team of experts, but the precise details are not spelled out. Strangely, it is not an issue in this campaign. Just as certain as night will follow day, Labour will oppose any solution proposed by the SDL. The reason? Politics. Keep politics out of the industry, people say, but that is naïve. Politics drives the sugar industry, always has. Mahendra Chaudhry's power base is in the cane belt; and he is the general secretary of the National Farmers Union. Farmers are slowly, visibly descending into poverty, while their leaders play politics and manoeuvre for political advantage, like vultures hovering eagerly over a mortally wounded animal.

Every major party has prepared a manifesto, a grab-bag of ideas and proposals about how they will address the social and economic problems facing Fiji. These are attractive documents, professionally produced, accessibly written and widely distributed. Though there are vernacular versions, the main one is in English. But these are for show really. Many candidates with poor English wave a copy furiously before their audiences, with all the pretended passion they can muster, urging them to read it when they themselves are innocent of its contents! Prepared speeches, rehearsed several times over, are the standard campaign fare. Politicians glibly tell people what they want, not what they ought, to hear. But manifestos have to be launched, a politician tells me, because without them, people would not take the party seriously. The ones loudest in their demands for manifestos are those who don't read, a candidate says to me slightly cynically. Complex ideas are reduced to laughter-inducing slogans. Voters want entertainment as well as (some) enlightenment.

The method of campaigning in Fiji has changed dramatically over the years. When I first began writing about elections in the early 1980s, large rallies were the order of the day. People travelled miles to listen to speeches. There was no television in Fiji then, and the video revolution was just beginning. So people turned up for rallies because these were a major item in their limited social calendar. By the late 1980s, cassettes began to be mass produced, carrying the party's ideas into distant rural areas, where people could listen to their leaders while sitting around the tanoa. Sakeasi Butadroka, the fiery Fijian nationalist, was among the first to use this medium. By the 1990s, pocket meetings had come to prominence and were used very effectively by the FLP. And with good reason too. Labour's organizational machinery, well-oiled and functioning 
efficiently, reached out to the grassroots. A handful of diehard supporters in each constituency was briefed - brainwashed may be a better word - to carry on the party propaganda while the candidate moved elsewhere. In the late 1990s, video cassettes were used, especially by the NFP to carry party leader Jai Ram Reddy's message on the constitution, but that trend did not catch on.

More recently, radio and television debates, phone-in programs, live interviews and, especially, advertising on television, have come to dominate election campaigns. SDL led the way in 2006 with slick advertisements - the white dove, the party's symbol, flying majestically against a light blue background - reminding the people of all it had achieved in the past five years and asking them not to jeopardize their future by voting for other parties. Labour focused on the real and alleged failures of the SDL government, highlighting the problems of poor water supply, unemployment and increased cost of living. Its advertisements, featuring despairing down-and-out people needing food, shelter and clean water, were pointed and hard-hitting in the characteristically Labour style. The NFP, strapped for funds, dusted up its 2001 campaign video for the 2006 election, screening exactly the same images but with a changed voice-over. No one noticed, which caused some bemused puzzlement among party leaders! The National Alliance launched a surprisingly well-funded media campaign, highlighting its connection to the legendary lights of the Fijian establishment: Ratu Sukuna, Ratu Edward Cakobau, Ratu George Cakobau and Ratu Mara, with a gently smiling party leader Ratu Epeli Ganilau holding up a lighted torch, marching towards a rising dawn. Slickly packaged television campaigns will be the order of the day in the future.

Campaign styles vary. Among Fijians, especially in rural areas, there is an acute awareness of cultural protocols governing public discourse. Voice is not raised and insulting language avoided. Un-chiefly conduct is frowned upon. I vividly recall a National Alliance meeting at Syria Park in Nausori. I was invited to the meeting. Ratu Epeli arrives in a new, rented four-wheel drive. Making a good impression is important. About two dozen people, mostly Fijian women from the neighbouring hinterland, are seated in a temporary corrugated iron shelter. At the appointed time, Ratu Epeli enters the speaker's shelter with his chiefly wife. They are seated on two elegant chairs facing the audience. Ratu Epeli is introduced. He reads a prepared speech, some of it in English. He is 
a dignified man, chiefly, well-spoken but wooden. He is critical of the SDL's policies, but never once does he directly attack the party or its leader. He talks about the need for the various ethnic groups to work together. He eschews racial politics. He talks about Fiji as a multiracial family. He is against racial discrimination in any form, including race-based affirmative action programs for Fijians. People clap politely when he finishes. Yaqona is served in the traditional Fijian way. He mingles with the crowd rather awkwardly. Style and status count as much as the substance of the speech. Snippets appear on the evening news and in the following day's papers.

After Ratu Epeli finishes, he asks me whether I might like to say a word or two. This catches me completely by surprise; I am unprepared. I realize quickly that Ratu Epeli is not inviting me, he is actually asking me to speak, in the traditional chiefly way. What to say? I begin with something I had read in the papers recently, some politician saying that racially polarized politics were inevitable, necessary even, because Fijians and Indo-Fijians could not, could never, work together. History was proof enough of that. I said in response that our history showed the contrary to be the case. Fiji had encountered seemingly intractable problems in its recent history, but our leaders had been able to resolve deep-seated difficulties through discussion and dialogue. Independence was a contested issue, but it was eventually achieved amicably. Our leaders were able to work together to devise ALTA, which had brought decades of prosperity to the country. Again, after the coups of 1987, they were able to retrieve the country from the brink of a precipice and conflagration. In the 1990s, Jai Ram Reddy and Sitiveni Rabuka, once bitter foes - Reddy was, after all, the chief target of the Taukei Movement in 1987: 'Reddy the Gun, Bavadra the Bullet', the placards had proclaimed - had been able to join hands to give the country the best constitution it ever had. We can work together, I said.

Meanwhile, the Prime Minister was telling his campaign audiences that Fijians were are not ready for a non-indigenous prime minister. And some SDL politicians were suggesting that the constitution should be changed to reflect the Fijian wish for the country to be led by Fijians. I said that I myself did not have a problem with a Fijian leader of government, provided that arrangement was the outcome of a political negotiation rather than a constitutional requirement. If race were further entrenched in the constitution, specifically the requirement 
that the prime minister should be a Fijian, we will once again court international sanctions. We will be expelled from the Commonwealth and strain our relations with our neighbours. With the population trend favouring Fijians - they would be about two thirds of the population in a decade or so - it was likely that a Fijian would always head government. Repeating my oft-spoken words, I said that this preoccupation with race was a prescription for political paralysis.

My words, echoing the sentiment Ratu Epeli had aired a few minutes earlier, received a warm response. He shook my hands in appreciation, and the women sitting in the shed clapped gently. I was moved, but wondered how much of what I had said was understood by the audience, for I had spoken in English. How I wished then that I could speak fluent Fijian, rather than communicating with my fellow countrymen in a language that none of us own or are truly comfortable with.

A week or so after the Nausori meeting, I attended an NFP rally in Suva. I had gone there to observe the proceedings and to catch up with old friends. I was a bit late and sat at the back of the room. Much to my surprise, the chairman announced my arrival to the audience and said, without my permission, that I would be speaking towards the end of the meeting! The speakers were full of fire and with a bagful of ideas about how to resolve the problems facing the country. Labour's strategies of 'boycott and high court' (someone mischievously added paraquat) were derided to quiet applause. In other meetings, as the campaign heated up, the rhetoric got hotter and more personal. Indo-Fijian audiences love chest-thumping, masala, talk.

After the last speaker had finished, I was invited to the front, still unclear in my mind about what to say. Then, all of a sudden, I remembered something I had read - or was told. In one of the meetings a year or two back, Mahendra Chaudhry had said that NFP stood for 'Not Fit for Parliament.' I began by reminding the audience that NFP had, in fact, played a very large role in Fiji's recent history. I asked the audience to name four of the most important achievements of Fiji in the last half-century. People look blankly. They are not used to this kind of interactive meeting. Achievement of independence, I suggest, is one. People nod in agreement. The Denning Award of 1969, which led to the departure of the Colonial Sugar Refining Company and brought prosperity to the sugar industry, is another. People are listening intently now. The successful 
negotiation of the Agricultural Landlord and Tenant Bill after independence - also a milestone achievement. And finally, I ask people not to forget the promulgation of the 1997 constitution, a momentous achievement considering the circumstances prevailing in the 1990s. I then make two concluding points. In all these four achievements of national importance, the NFP had played a key role: that was a matter of historical record and no trimming of the truth could alter that fact. And second, I say these achievements came about as a result of dialogue and discussion, patient negotiation and sensitive appreciation of the fears and aspirations of Fiji's different communities. People clap warmly as I sit down. I hadn't said anything terribly profound, but I realize as I ponder the event later that our people, even political leaders, have a poor understanding of history, even the recent history of their own party.

The NFP puts on a brave face, but even the most optimistic assessment by party insiders gives them just a handful of seats, anywhere between three and eight. They can't be kings, its leaders realize, but they could be king-makers by distributing their preferences wisely and perhaps, as a bonus, get a Senate seat or two. Its most critical handicap in this election is that there is no clear, and in the public's mind clearly identifiable, leader; no one face of the party. Attar Singh, Pramod Rae and Raman Singh take turns to represent the party in various fora, but that only serves to compound the problem. On this front, Labour has a considerable advantage. Mahendra Chaudhry is the public face of the party, its brand name. For many, Chaudhry is the Labour Party.

In the Fijian electorate, Laisenia Qarase enjoys a similar advantage. $\mathrm{He}$ is no longer the shy, awkward campaigner of 2001, unsure of himself and dependent on others for advice. In 2006, he is relaxed, confident, skilled at public speaking, engaging. He is the undisputed leader of the SDL, which he has, over the course of five years, built into a cohesive, well-oiled fighting machine. His most prominent Fijian challenger, Ratu Epeli Ganilau, is also a well-known name from a distinguished family, but his base is limited and his platform of multiracialism drowned out by the politics of racial polarization. Qarase's advocacy of race-based affirmative action policy and his frequently aired view that Fijians must continue to lead the country fall on receptive ears. The fear of Chaudhry returning to lead pushes many Fijians into the SDL camp. 'Do you want Mr Chaudhry to lead this country?' Qarase asks his audiences 
repeatedly, and the response always is a thunderous 'No'. A Fijian taxi driver tells me that he admires Chaudhry for his courage, but he does not trust him. To him, the Labour leader is politically too smart for his opponents; he always has something up his sleeve. He was not alone in thinking that.

Personalities certainly matter, but both SDL and Labour have done their homework. Qarase has made sure that in his policies and programs no province is left out. The provincial link is assiduously cultivated, and the party's network reaches deep into the Fijian hinterland. The SDL is not officially endorsed by the Great Council of Chiefs, as the Soqosoqo ni Vakavulewa ni Taukei (SVT) was in the 1990s, but people know that its blessing is with it. Any opportunity to 'explain' the government's policies - the RTU Bill, for example - to the provinces is seized to strengthen the party's connection with the grassroots, reminding them of what the government has accomplished. With the disestablishment of the Conservative Alliance-Matanitu Vanua party, SDL became the umbrella party of the Fijian community. The SVT is a ghost of its former self, fielding only one candidate, that too an Indo-Fijian! Like the SDL, Labour's machinery is strong. The National Farmers Union, the Fiji Public Service Association and the Fiji Teachers Union are all identified with Labour. Parliamentarians are regularly required to keep in close touch with their constituents. Chaudhry himself sets the example that others can ignore only at their peril.

Voters have become more sophisticated over the years. Now, they are keenly aware of the power they have in their hands. They know that they own the vote. They expect the candidates to come to them, to sit down with them, serve them kava and cigarettes, attend their marriage and funeral functions. They expect to be picked up from their homes and transported to the polling booth - at a time convenient to themselves. Candidates from all political parties complain about the expense incurred in entertaining voters. Many say that they have spent more than $\$ 10,000$ of their own money during the campaign, most of it on providing kava. I am amazed at how much kava is drunk these days. Any excuse to mix a bowl. A party worker tells me that in his constituency, meetings go well into the night. 'That's good', I say, thinking that people are really engaged with the campaign. 'No, Doc, nothing like that. They want long meetings so that they can drink more free grog.' In Fijian meetings I observe, yaqona is drunk, but protocol and rank are recognized. The spirit of the vanua is honoured and 
outsiders are formally welcomed. But among Indo-Fijians, yaqona is consumed in copious amounts, without decorum or dignity. Excessive yaqona drinking among Indo-Fijian men is a major cause of domestic problems and extramarital affairs, which sometimes end in tragedy. The sad thing is that yaqona drinking is becoming increasingly popular among younger people.

Politicians try hard to meet their public obligations, but sometimes things go wrong. A man tells me that when his wife died in a tragic fire accident, the politician representing his constituency felt obliged to make an appearance. He walked up to the bereaved husband, and asked him if he knew who the dead woman was! The man decided there and then not to vote for that parliamentarian ever again. Another candidate told me that when she visited one particular household, an elderly lady told her that she would vote for her provided she increased her monthly allowance. She was honest enough to say that she would try but could not promise. The old woman abruptly shut the door on her. The changing voter behaviour, at least in the Indo-Fijian community, is producing a new kind of politician, one who is attentive to the needs of the constituency almost to the exclusion of any other consideration, who spends most available time and energy mixing with constituents, ministering to their personal needs. Whether the candidate would make a good parliamentarian and legislator capable of handling complex national policy issues is, sadly, a secondary matter.

I encounter a range of opinion as I travel the countryside. Most talks are depressing: non-renewal of leases, unemployment, discrimination in the public sector, people waiting hopefully for their children to emigrate so that they, too, could go. But there are light moments as well. Without humour, it would be difficult to cope, I realize. A middle-aged man in Tavua town assures me over a bowl of grog that there has been real progress in Fiji since 1987. Progress? How? 'Look, Doc', the man says, 'in 1987, our government lasted one month, in 2000 it lasted one year. Next time, it will last two years, no?' A thigh-slapping laugh follows. 'Let's hope it lasts much longer', I reply, joining in the laughter. A man in Rakiraki tells me he will vote Labour. Before I am able to say anything, he says, 'If Labour wins, there will be trouble. We will then have a better chance to migrate'. This reminds me of an incident in Sydney when some protestors hoisted a banner saying 'Speight ke Maro Goli'. This could read as 'To hell with 
Speight' or 'Shoot Speight'. The protestors had the latter in mind. A man tells me, 'We will get ourselves photographed in front of parliament house and will use the photograph to claim political asylum in Australia!'

Other stories. A man says he will never vote for NFP because it is a rich man's party. Another replies: 'Arre, you should vote for a rich man's party: what can a poor man's party do for you?!' At another place, a man relates a story which has been around for a while. Someone says he will never vote for NFP because NFP is not known outside Fiji. There is a Labour party in the UK, and in Australia and New Zealand, but there is no NFP there. 'How can you expect help for a party no one knows about overseas?' A candidate in Tavua says they should vote for Mahendra Chaudhry because he is a man of courage. 'I was a hostage for nearly two months. I saw with my own eyes the terrible beating the soldiers gave to my leader. I saw blood on his face. His ribs were broken. But he did not flinch.' People are impressed. But a week later the local headmaster visits the area and is told the story. He is puzzled. How could the candidate have seen Chaudhry being beaten 'with his own eyes' when he was not in parliament and never incarcerated? Trimming the truth: everyone seems to be doing it.

People devise ingenious ways of getting their message across to the people. At one meeting, a candidate asks people to vote for the vara, the germinating coconut tree which is the FLP symbol. Why? Because coconut is offered to the gods in Hindu religious ceremonies. 'Coconut water is the purest form of water, untouched by human hands', he says. What that has to do with politics is beyond me. But at another meeting, an NFP candidate responds to this by saying that, yes, coconut water is the purest form of water, but we offer it to the gods using the mango leaf. The mango tree is the symbol of the NFP!

There is much talk about the poor calibre of candidates standing in this election. How can candidates with limited education be entrusted with making decisions about the country's future, people ask. Many are barely able to put two sentences in English together: how will they be able to digest complex bills in parliament? The point is taken, though it is easy to say this while sitting on the sidelines. The calibre of Fijian candidates is better than the calibre of Indo-Fijian candidates. Fijians see a future in politics for themselves. IndoFijians don't. Some of them are standing because they are retired, have nothing 
useful to do, and are looking for a bit of fame and fortune before the flame is finally extinguished. Some are standing because they believe passionately in some cause or because their party has asked them to. Their sense of loyalty and perseverance commands respect.

At the beginning of the campaign, almost every candidate I speak with is hopeful about his or her prospect. 'Chance hai.' We have a chance. But hope begins to vanish as the campaign proceeds. It is a sad spectacle. The saddest though is the fate of those who, having done their arithmetic, know from the very beginning that they have no hope of winning at all. But they put on a brave face, go through the motions and campaign house-to-house. How they can muster the energy and enthusiasm to go on the campaign trail in humid heat and dust, day in, day out, over several weeks defies easy comprehension. I suppose hope springs eternal in the heart of every prospective politician. Some hope to make enough acquaintances to help their business. For others, this is a trial run, an apprenticeship for the next time around. At least one candidate tells me that the exposure he has gained in this campaign will help his chances for selection in the municipal elections.

As I travel around the countryside, usually by myself, I often think how things have changed over the years. I published my first Fiji election analysis in 1983. There was no internet then, no websites, no email, no googling, just the radio and the newspapers. Gathering data - about the demographic and ethnic composition of a constituency, for example, or getting hold of party manifestos or profiles of candidates - was tedious and time consuming. Luck played a large part in acquiring the election marginalia so essential to understanding the mood of the campaign. But all that has changed. All the data you need are now posted on the official election website. Both SDL and Labour have their own websites, displaying their manifestos and speeches by their leaders. All the major newspapers have their own websites, carrying analysis as well as information. Expert commentary is copied and carried far and wide. It is possible now to 'know' what is happening on the hustings without leaving your computer desk. The kind of detailed analyses I wrote earlier seems inappropriate now because everyone who wants to can have access to the same data set. I have become a remnant in my own lifetime! 
As the day of reckoning draws near and all the campaign propaganda have been distributed, attention turns to the logistics of manning the polling booths: sheds will have to be erected, transport arranged, food and grog organized, trusted party workers found to look after the booth. And the waiting, the endless waiting for the D-Day. As I say goodbye to the campaign trail, with some sadness I have to admit, I know in my heart that the friendships I have made with people in once exotic and unknown places, such as Balata, Dabota, Tagi Tagi and Garampani, will remain with me for a very long time, reminding me of the world I once knew so intimately, but of which I am no longer a part. Fate has dealt these folk a cruel hand. Often they suffer through no fault of their own, victims of other people's envy and avarice. I hope and pray that, whatever the final outcome, the verdict of the ballot box will be respected and that citizens of this most beautiful of lands on earth will be given an opportunity to fashion the future of unity and prosperity that they so richly deserve and which is within their reach.

\section{Notes}

1 Small meetings with a handful of supporters in the constituency, largely away from the media and usually around a yaqona bowl. 